\title{
The Discovery of Coronavirus - An Interesting Journey
}

\author{
Kaushik Bhattacharya ${ }^{1^{*}}$ (D), Neela Bhattacharya ${ }^{2}$ (D) , Aditya Shikar Bhattacharya ${ }^{3}$ (D)
}

\begin{abstract}
\section{Keywords}

Coronavirus; Electron Microscope; Rubella; Common Cold

${ }^{1}$ CAPF Composite Hosp BSF Kadamtala, G616, Siliguri 734010, West Bengal, India

${ }^{2}$ Anandaloke Multispeciality Hospital, Siliguri, West Bengal, India

${ }^{3}$ Stanley Medical College, Chennai, Tamil Nadu, India

*Corresponding author: kbhattacharya10@yahoo.com
\end{abstract}

The coronavirus, which is causing the ongoing Covid-19 pandemic and has crippled the entire world, was discovered by June Dalziel Almeida - a school dropout from Scotland who had no formal medical education. She had to master the knowhow of immune electron microscopy to climb up the academic ladder and she finally discovered the coronavirus only to see her research paper getting rejected by reputed journals. A single mother is now associated with the coronavirus, as well as with a significant contribution to the classification of viruses, viral imaging and bringing Rubella virus, Hepatitis B virus and Human immunodeficiency virus into the limelight.

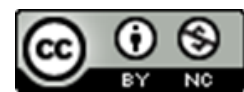

\section{Introduction}

June Dalziel Almeida, who brought up in Glasgow, wanted to learn about biology, science, and nature and even though she was awarded the Whitehill School's science prize by her school, she had to drop out of school in the post-World War II scenario, due to economic hardship [1]. No one could have ever imagined that one day June Almeida, a daughter of a Glasgow bus driver, will become the first virologist to discover the human coronavirus (Fig. 1).

She was hailed by Professor Hugh Pennington, Emeritus Professor of Bacteriology at Aberdeen University, as "one of the greatest scientists of her generation but sadly largely forgotten" [2]. Without her pioneering work, things would have been much more tedious in dealing with the current coronavirus outbreak. Her work has sped up our understanding of the virus [3]. She was a pioneer with an outstanding talent. Her work, which is now helping in the fight against Covid-19, should have entitled her a place in the hall of fame of eminent virologists.

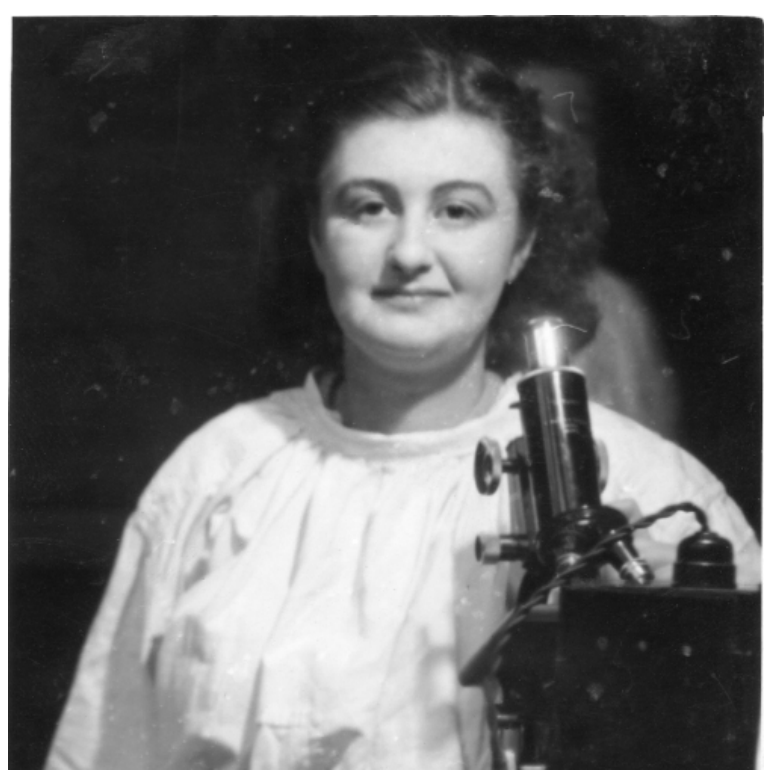

Figure 1. June Almeida (1930-2007). Credit: Joyce Almeida. 


\section{Personal Life}

June Hart was born to Jane Dalziel and Harry Leonard Hart on October $5^{\text {th }}, 1930$, at 10, Duntroon Street, Glasgow. Harry Leonard Hart was working as a bus driver and could not afford fees for his daughter's education and June had to drop out of school at 16 years, to work as a histopathology technician at Glasgow Royal Infirmary for a salary of 25 shillings per week [4]. She then moved to St Bartholomew's Hospital to continue her career with no formal higher education medical degree. She lost her 6-year-old brother in 1940 to diphtheria and this personal tragedy made her more resilient to learn about biological sciences. She got married to Enrique Rosalio Almeida, a Venezuelan artist, in 1954 and moved to Canada where she joined the Ontario Cancer Institute (now Princess Margaret Cancer Centre) as an electron microscopist. She got divorced in 1967 and had to raise her only daughter, Joyce, as a single parent. She married again in 1982 to her fellow clinical virologist Philip Gardner in 1982 who taught her the immunofluorescence technique for the rapid diagnosis of many viral infections [1].

\section{Initial Career with Electron Microscopy}

Opportunity knocked the June Almeida's door when she got the chance to work with the electron microscope at the Ontario Cancer Institute. By 1958, she had mastered the use of an electron microscope and a technique called negative staining, in which a heavy metal, typically phosphotungstic acid, was used to enhance the contrast in the images. She never realised that one day she would use this method to detect the coronavirus. She commented "negative staining allowed the electron microscope to become one of the fastest and most efficient means of identifying a virus" [5]. She extended the use of the electron microscope to find the relationship between the virus and cancer. She captured the first image of Rubella virus and Hepatitis B virus [6]. Next, she pioneered the technique of Immune Electron Microscopy (IEM). She found it easy to pick up virus with IEM as antibodies were used to clump viruses. She trained Albert Kapakian, an Armenian-American virologist, at the National Institute of Health in IEM which helped him discover Norovirus, a virus causing gastroenteritis which was named Norwalk virus. June Almeida's pioneering work with IEM paved the way for the classification of viruses and the International Committee on Taxonomy of Virus was formed in 1966. Kenneth McIntosh, Professor of Paediatrics at Harvard Medical School, made the observation after seeing the June Almeida's work: "Attention to detail, patience and persistence. June Almeida had those qualities in spades" [7].

\section{Academic Career}

June Almeida was once asked in 1993 how she discovered Hepatitis B virus, she answered as a modest person: "I just happened to be in the right place at the right time". Her daughter, Joyce Almeida, once commented about her mother: "She valued individuals in their own right, not for their standing in life" [8].

June Almeida had 103 publications in various medical journals and textbooks. By 1970, she was appointed as Senior Lecturer at Hammersmith and subsequently she was recruited by the Wellcome Research Laboratories in Beckenham, Kent. She was awarded the first formal degree - Doctor in Science for her publication in 1970 [9].

In 1980, she joined St Thomas Hospital as an advisor and used to work one day per week and here, she published the first high quality image of Human Immunodeficiency Virus. She had a high sense of humour which can be seen from her publication in 1963 where she paid an ode to the electron microscope, with an apology to the poet William Blake [10] -

\section{"Virus, virus shining bright, In the phosphotungstic night, What immortal hand or eye, Dare frame thy fivefold symmetry."}

After the retirement from virology in 1985, June Almeida became a Yoga instructor and antique dealer. She was one of the contributors who helped shape the World Health Organisation's 1979 Manual for Rapid Laboratory Viral Diagnosis. She died on December $1^{\text {st }}, 2007$, at the age of 77 at Bexhill, UK.

\section{The Corona Discovery}

In 1964, June Almeida was contacted by Dr David Arthur John Tyrrell, a British virologist, the Director of the Common Cold Unit in Salisbury, as one nasal swab sample collected from a boarding schoolboy from Surrey in 1961 and designated as "B 814" was becoming difficult to maintain in a culture and cultivate it even after 4 years of preservation. With no other option being available, Tyrrell sent the sample to June Almeida, hoping that her electron microscope could identify the virus. His comment in his book "Cold Wars: The Fight Against the Common Cold' was "We were not too hopeful but felt it was worth a try" [10].

On putting the mysterious pathogen samples under the microscope, Almeida noticed that B814 had a structure similar to influenza viral particles. She knew that she was on the verge of discovering a new family of viruses with short spikey projections on the outer surface, appearing as a solar corona which led June Almeida and Tyrrell to call the new group "coronavirus" - derived from the Latin word "corona" meaning "crown" or "halo" [2].

When the research on the new virus was sent for publication, the journal refused to accept the finding, as the reviewer found Almeida's micrographs of B814 virus as "just bad pictures of influenza viruses." June Almeida and Tyrrell had to literally struggle to get the work finally published in the Journal of General Virology in 1967 [1]. 


\section{June Almeida and Covid-19}

No one could understand the importance or gravity of the invention of the coronavirus by June Almeida until there was a sudden outbreak of severe acute respiratory syndrome (SARS). In 2019, when a strange disease first appeared in Wuhan, China, researchers used Almeida's pioneering work to identify the culprit as another type of coronavirus - a type called "SARS-CoV-2" which was the reason for the Covid-19 pandemic. Unfortunately, June Almeida died before she could enjoy the wide recognition of her work. She was that person who deserved a Nobel Prize in Medicine. Her daughter Joyce made the final comment about her mother in the British Medical Journal in 2008: "True to form, she could not leave electron microscopy forever" [10]. In September 2020, Guy's hospital opened a new COVID-19 testing laboratory and named it after June Almeida [11].

\section{Conclusions}

\author{
"What she touched in her \\ research turned to gold" \\ Professor Hugh Pennington, \\ Emeritus Professor of Bacteriology \\ at Aberdeen University.
}

It had been a miraculous and fascinating journey for a daughter of a Scottish bus driver, who dropped out of school at 16 years with no formal education, a single parent, who mastered the electron microscope with sheer hard work and perseverance and finally was able to diagnose, image and classify the coronavirus, a virus which has been the principal cause of the ongoing pandemic in the $21^{\text {st }}$ century.

\section{Ethical Statement}

This article does not include any human participants and/or animals.

\section{Conflict of Interest}

The authors declare that no conflicts exist.

\section{Financial Disclosure}

The authors declared no financial support.

\section{References}

[1] June Almeida [Internet]. What is Biotechnology? 2020 [cited 2021 Jul 10]. Available from: https://www.whatisbiotechnology.org/

[2] Combs S. She discovered coronaviruses decades ago - but got little recognition [Internet]. National Geographic. 2020 [cited 2021 Jul 10]. Available from: https:/www.nationalgeographic.com/history/article/junealmeida-discovered-coronaviruses-decades-ago-littlerecognition
[3] Pallister K. Dr June Almeida: the scientist who identified the first human coronavirus [Internet]. IFLScience. 2020 [cited 2021 Jul 10]. Available from: https://www.iflscience.com/editors-blog/dr-junealmeida-the-scientist-who-identified-the-first-humancoronavirus/

[4] Almeida J. June Almeida (née Hart). BMJ. 2008;336(7659):1511.1-1511. Available from: https://doi.org/10.1136/bmj.a434

[5] Stanton JM. Health policy and medical research: hepatitis B in the UK since the 1940s [dissertation]. London: London School of Hygiene \& Tropical Medicine; 1995. Available from: https://doi.org/10.17037/PUBS.00682243

[6] History of medical photography. In: Pasquali P, editor. Photography in clinical medicine, 1st Edition. Springer International Publishing; c2020. Available from: https://doi.org/10.1007/978-3-030-24544-3

[7] Carpenter J. A woman to know: June Almeida [Internet]. A woman to Know. 2021 [cited 2021 Jul 10]. Available from: https://awomantoknow.substack.com/p/a-womanto-know-june-almeida

[8] Almeida J. Words and phrases to describe my mother, June Almeida.

[9] Brown A. Pioneers in science: June Almeida [Internet]. Advanced Science News. 2020 [cited 2021 Jul 10]. Available from: https://www.advancedsciencenews.com/pioneersin-science-june-almeida/

[10] Gellene D. Overlooked no more: June Almeida, scientist who identified the first coronavirus [Internet]. The New York Times. 2020 [cited 2021 Jul 10]. Available from: https://www.nytimes.com/2020/05/08/obituaries/junealmeida-overlooked-coronavirus.html

[11] Guy's and St Thomas' NHS Foundation Trust. Guy's Hospital names Covid lab after pioneer who discovered the virus [Internet]. 2020 [cited 2021 Jul 10]. Available from: https://www.guysandstthomas.nhs.uk/news-andevents/2020-news/september/20200908-guys-hospitalnames-covid-lab-after-pioneer-who-discovered-thevirus.aspx

Received: 2021-07-10

Revised: 2021-07-20

Accepted: 2021-07-23 